\title{
MODELOWANIE NUMERYCZNE NIEJEDNORODNOŚCI STRUKTURY WYPEŁNIENIA ZŁĄCZY W BUDYNKACH WIELKOPŁYTOWYCH
}

\author{
Wojciech Górski ${ }^{\boxplus 凶}$, Jarosław Szulc ${ }^{2}$ \\ ${ }^{1}$ Wydział Budownictwa i Inżynierii Środowiska, Szkoła Główna Gospodarstwa Wiejskiego, Warszawa \\ 2 Instytut Techniki Budowlanej, Warszawa
}

\begin{abstract}
STRESZCZENIE
Artykuł dotyczy zagadnień bezpieczeństwa i trwałości budynków wzniesionych w technologiach wielkopłytowych w latach 1960-1990. W tym okresie na różnych etapach procesu inwestycyjnego dochodziło do wielu nieprawidłowości, które mogły skutkować obniżeniem jakości wykonawstwa budynków i powstawaniem wielu różnych defektów m.in. w obszarze złączy konstrukcyjnych między elementami prefabrykowanymi. W artykule wskazano możliwość wykorzystania modelowania numerycznego do oceny pracy połączeń, w których występuje np. niejednorodność struktury materiału wypełniającego (tzw. raki). Do analiz wybrano poziome złącza stropu i wewnętrznej ściany nośnej wykonane w systemie centralnym Wk-70. W pracy przedstawiono wyniki wariantowych symulacji komputerowych pracy tzw. złącza referencyjnego oraz złączy zawierających zmienny udział, rozmieszczenie i kształt defektów. Wyniki obliczeń mogą stanowić podstawę do wskazania kierunków prac diagnostycznych budynków wielkopłytowych, oceny stanu technicznego konstrukcji i podjęcia decyzji o jej naprawie lub wzmocnieniu.
\end{abstract}

Słowa kluczowe: budownictwo wielkopłytowe, system Wk-70, złącza konstrukcyjne, MES, defekty, ocena techniczna

\section{WSTĘP}

Istotnym elementem zapewniającym integralność i spójność ustroju konstrukcyjnego budynków wielkopłytowych były połączenia między wielkogabarytowymi elementami prefabrykowanymi. W okresie wznoszenia budynków prowadzono liczne prace naukowo-badawcze ukierunkowane na poprawę jakości tych złączy i eliminowanie możliwości nieprawidłowego ich wykonania (Szulc, 2017; 2018; 2019a). $\mathrm{W}$ miejscach połączenia elementów wprowadzano kolejne modyfikacje - pomimo tego zabiegu złącza nadal stanowią ,,słaby punkt” w aspekcie rozkładu sił przestrzennego ustroju nośnego. Występujące dodatkowo nieszczelności złączy oraz inne wady wykonawcze stanowiły źródło pojawiających się wątpliwości odnośnie właściwego stanu technicznego budynków wielkopłytowych (Dębowski 2012a; 2012b; Ligęza, 2014; 2015).

Według Ligęzy i Dębowskiego (2007) spośród zasadniczych przyczyn powstawania defektów w systemie Wk-70 można wymienić:

- etap projektowania: nieuwzględnienie rzeczywistych tolerancji w produkcji elementów,

$\bowtie$ wojciech_gorski@sggw.pl 
- etap produkcji: niedobory zbrojenia, zła jakość betonu, wadliwe jego zagęszczenie i nieprawidłowa pielęgnacja, uszkodzenie prefabrykatów,

- etap transportu i składowania,

- etap montażu: odchyłki montażowe i wadliwa rektyfikacja, wadliwe wykonanie zbrojenia i spawów montażowych, nieodpowiednia grubość zaprawy w tzw. podlewach, montaż obiektów w nieodpowiednich warunkach atmosferycznych.

Zakres defektów w złączach konstrukcyjnych determinuje możliwość dalszej eksploatacji budynków (rys. 1). Określenie stanu alertowego, przy którym może dojść do awarii lub katastrofy, jest zagadnieniem kluczowym dla zapewnienia bezpieczeństwa użytko- wania budynków oraz ewentualnego podejmowania decyzji o ich wzmocnieniu.

Jednym z możliwych defektów złączy są tzw. raki $\mathrm{w}$ betonie, czyli puste przestrzenie w strukturze wypełnienia (rys. 2); mogą być one zlokalizowane przy powierzchni lub wewnątrz elementu konstrukcyjnego (Szulc, 2017; 2019b). Raki powodują zmniejszenie sztywności i nośności złącza, co w konsekwencji pogarsza parametry wytrzymałościowe innych elementów konstrukcyjnych. W sytuacjach, gdy dochodzi do odsłonięcia zbrojenia i bezpośredniego oddziaływania agresywnych czynników zewnętrznych, powstaje również zagrożenie korozyjne stali zbrojeniowej i obniżenie trwałości połączenia (Szulc, 2017).

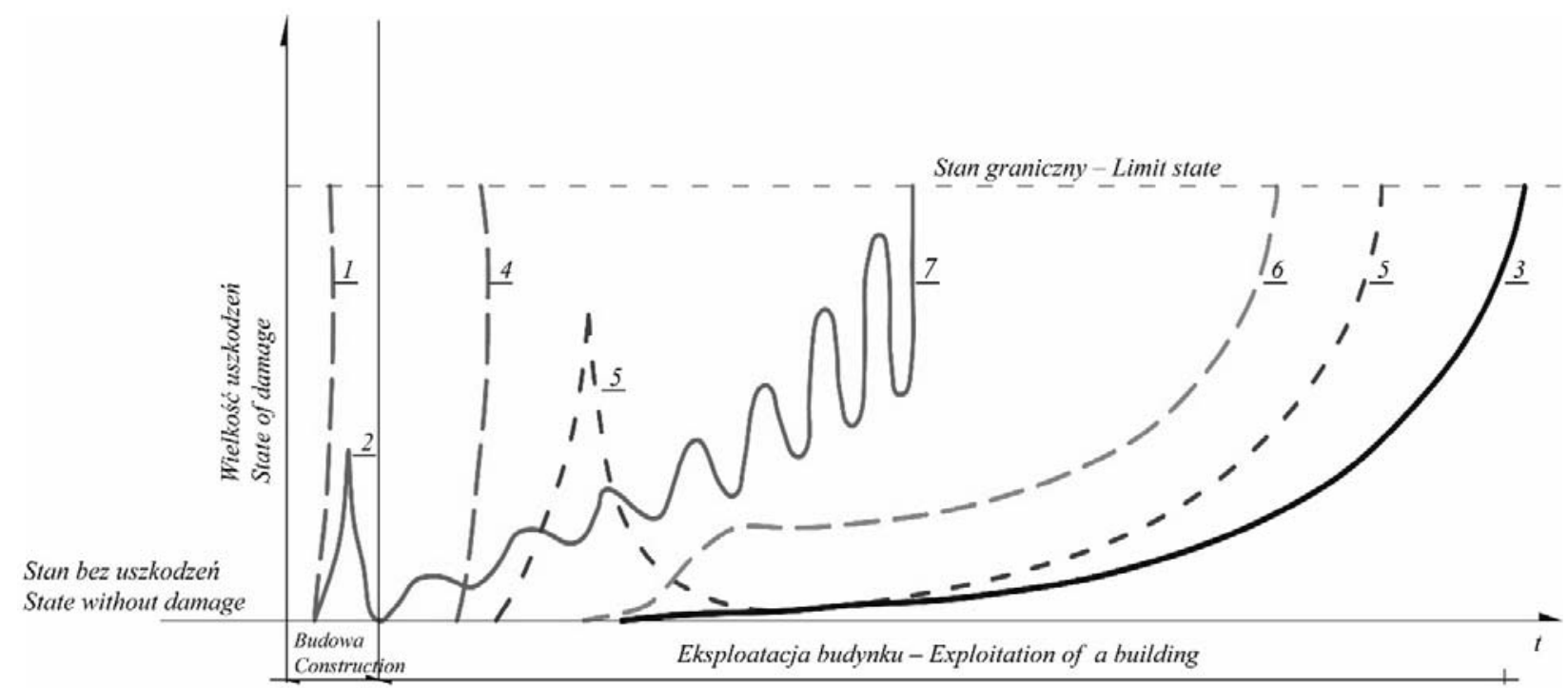

1 - zniszczenie całej konstrukcji w czasie budowy (katastrofa) - destruction of the whole structure during construction

2 - uszkodzenie fragmentu konstrukcji w czasie budowy (dalsza realizacja obiektu możliwa po jego usunięciu) - damage to a part of the structure during construction (further construction works possible after its removal)

3 - prawidłowo zmieniający się stan konstrukcji, wyłącznie na skutek naturalnego zużycia, przedłużany przez prawidłową konserwację - correctly changing condition of the structure, only due to natural wear, prolonged by proper maintenance

4 - awaria całej konstrukcji w czasie eksploatacji - failure of the entire structure during exploitation

5 - uszkodzenie fragmentu konstrukcji w czasie eksploatacji (dalsza eksploatacja obiektu możliwa po jego usunięciu) - damage to a part of the structure during exploitation (further exploitation of the object possible after its removal)

6 - uszkodzenie w czasie eksploatacji (stabilizacja w dowolnym czasie) - damage during exploitation (stabilization at any time)

7 - uszkodzenie w czasie eksploatacji, a jego wielkość jest cykliczna w całym okresie - damage during exploitation and its magnitude is cyclical throughout the period

Rys. 1. Schematy możliwych uszkodzeń budynku wykonanego w technologii uprzemysłowionej (na podstawie Dębowski, 2012a)

Fig. 1. Schemes of possible damage to the building (on the basis of Dębowski, 2012a) 

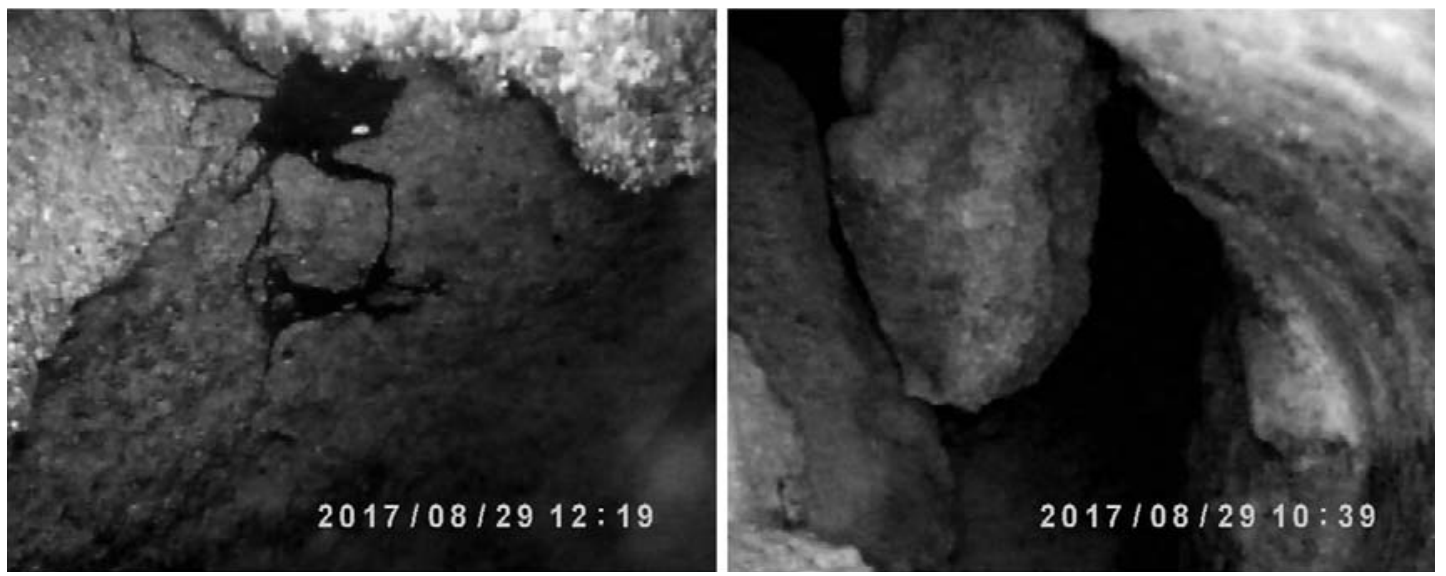

Rys. 2. Przykłady praktyczne występowania niejednorodności struktury wypełnienia złączy (tzw. raków) uzyskane z badań istniejących złączy konstrukcyjnych budynków wybudowanych w systemie Wk-70 (widok z kamery inspekcyjnej)

Fig. 2. Practical examples of the occurrence of inhomogeneities in the structure of joints filling (so-called cancers) obtained from testing existing construction joints of buildings built in the Wk-70 system (view from the inspection camera)

\section{ZAKOŻENIA I METODYKA OBLICZENIOWA}

Przeprowadzone analizy numeryczne zostały ukierunkowane na rozwiązanie następujących zagadnień merytorycznych:

- seria obliczeniowa I: analiza ukierunkowana na walidację referencyjnego modelu obliczeniowego na podstawie wyników badań doświadczalnych $\mathrm{w}$ zakresie identyfikacji charakteru zniszczeń złącza,

- seria obliczeniowa II: analiza wariantowa określająca jakościowy i ilościowy wpływ kształtu raków na stan naprężenia elementów złącza,

- seria obliczeniowa III: analiza wariantowa uwzględniająca zmienność lokalizacji i nasycenia raków w wypełnieniu oraz wpływ tych parametrów na stan naprężenia i odkształcenia elementów złącza.

\section{Seria obliczeniowa I}

Walidacja modelu referencyjnego ( $\mathrm{tj}$. bez odwzorowania defektów) została przeprowadzona na podstawie wyników doświadczalnych uzyskanych podczas badań wytrzymałościowych złącza konstrukcyjnego Wk-70 (Pogorzelski, 1982) - schemat doświadczenia na rysunku 3.

Geometrię przestrzenną złącza określono na podstawie dokumentacji projektowej systemu Wk-70

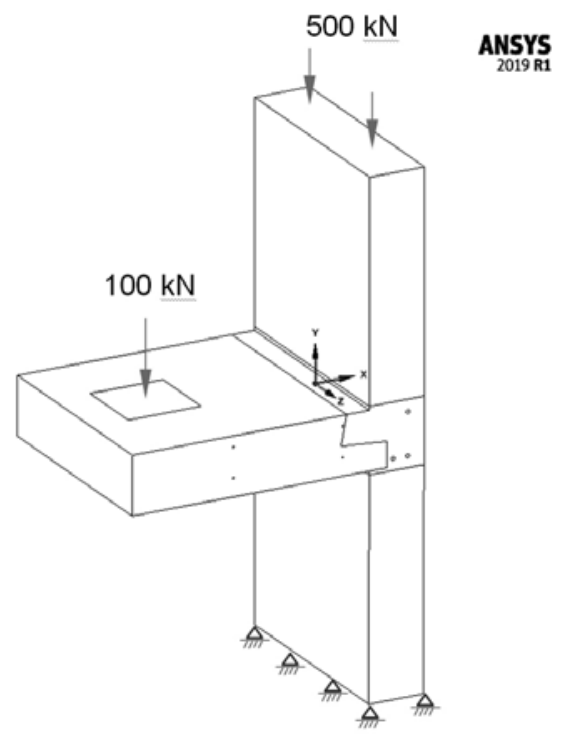

Rys. 3. Model badawczy złącza konstrukcyjnego - schemat statyczny i obciążenia

Fig. 3. Model of the structural joint - static scheme and loads

z wykorzystaniem programu ANSYS SpaceClaim Direct Modeler (rys. 4).

Analizie numerycznej poddano złącze poziome $\mathrm{S}+\mathrm{W}$, tj. połączenie elementów stropowych o grubości 


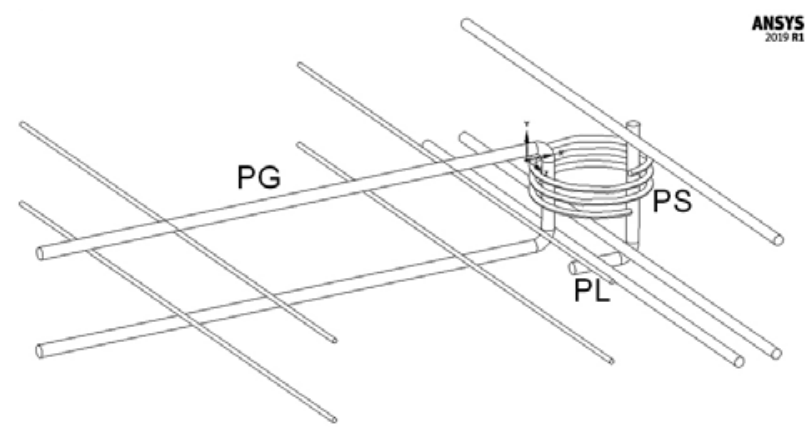

Rys. 4. Oznaczenia prętów zbrojeniowych elementów złącza (opis w tekście)

Fig. 4. The designation of the reinforcing rods of joint elements (explanations in the text)

$16 \mathrm{~cm}$ i ściany wewnętrznej (górnej i dolnej) o grubości $15 \mathrm{~cm}$.

Pręty zbrojenia elementów złącza (rys. 4) oznaczono jako: PG - pręt główny zlokalizowany w płycie stropowej (stal 34GS), PL - pręt rozdzielczy płyty stropowej (stal 34GS), PS - zbrojenie złącza (stal S185).

Analizę numeryczną modelu referencyjnego (model I-1) przeprowadzono z wykorzystaniem solvera Explicite Dynamics, który umożliwia obserwację inicjacji, prędkości rozchodzenia się i przebiegu zarysowań, pęknięć i zniszczeń materiałowych. W analizie tej elementy skończone, w których zostają przekroczone wartości graniczne parametrów są sukcesywnie „wyłączane” w modelu i nie biorą udziału w kolejnych krokach obliczeniowych.

\section{Seria obliczeniowa II}

W celu określenia wpływu kształtu raków na zmiany rozkładu naprężeń zbudowano trzy modele obliczeniowe:

- model II-1: model wyjściowy będący prostopadłościanem o wymiarach $100 \times 100 \times 200 \mathrm{~mm}$ bez niejednorodności struktury,

- model II-2: zawierający defekty (raki) o kształcie kuli o średnicy $25 \mathrm{~mm}$,

- model II-3: zawierający defekty (raki) w postaci graniastosłupa prostego o długości krawędzi podstawy 31,62 mm i wysokości równej $25 \mathrm{~mm}$.

$\mathrm{W}$ modelach numerycznych raki zostały zlokalizowane w środku ciężkości modelu wyjściowego, obliczenia wykonano z wykorzystaniem solvera Explicite Dynamics.

\section{Seria obliczeniowa III}

$\mathrm{W}$ analizie pracy przestrzennej złącza konstrukcyjnego ze zmiennym udziałem (nasycenia) niejednorodności struktury materiału wypełnienia wykorzystano cztery modele (rys. 5):

- model III-1: model wyjściowy (bez defektów),

- model III-2: model zawierający defekty (raki) równomiernie rozłożone $\mathrm{w}$ materiale wypełnienia (nasycenie ok. $2 \%$ ),

- model III-3: model zawierający defekty (raki) zlokalizowane poza elementami zbrojenia złącza (nasycenie ok. $22 \%$ ),

- model III-4: model zawierający defekty (raki) zlokalizowane w obszarze elementów zbrojenia złącza (nasycenie ok. 32\%).

Raki w modelach obliczeniowych zostały wprowadzone jako pustki powietrzne o kształcie prostopadłościanów o wymiarach $30 \times 30 \times 30 \mathrm{~mm}$.

$\mathrm{W}$ analizach wykorzystano algorytmy i zasady nieliniowej analizy statycznej; w zakresie stanu naprężenia poniżej wartości granicznych wytrzymałości materiałów uzyskane wyniki (model III-1) były zbieżne $\mathrm{z}$ wynikami analiz modelu referencyjnego (model I-1) z wykorzystaniem modułu Explicite Dynamics.

\section{WYNIKI ANALIZ NUMERYCZNYCH ZŁĄCZY}

\section{Seria obliczeniowa I}

Zasadniczym celem tej analizy było potwierdzenie zgodności charakteru zniszczenia elementów złącza konstrukcyjnego (model I-1) z wynikami badań doświadczalnych według Pogorzelskiego (1982) - w efekcie uzyskano zbieżność weryfikującą pozytywnie poprawność modelu i przyjętych założeń obliczeniowych (rys. 6).

Wybrane wyniki analizy numerycznej złącza konstrukcyjnego Wk-70 (model referencyjny) przedstawiono na rysunku 7; wartości maksymalne i minimalne odnoszą się do naprężeń w elementach zbrojenia złącza.

Na rysunku 8 pokazano kolejne etapy propagacji uszkodzeń elementów konstrukcyjnych złącza; w kolejnych krokach obliczeniowych, po zainicjowaniu procesu zarysowania betonu, dostrzeżono efekty redystrybucji sił wewnętrznych, m.in. wyraźny wzrost naprężeń w prętach zbrojeniowych. 
Górski, W., Szulc J. (2019). Modelowanie numeryczne niejednorodności struktury wypełnienia złączy w budynkach wielkopłytowych. Acta Sci. Pol. Architectura 18 (2), 79-92, DOI: 10.22630/ASPA.2019.18.2.25

a

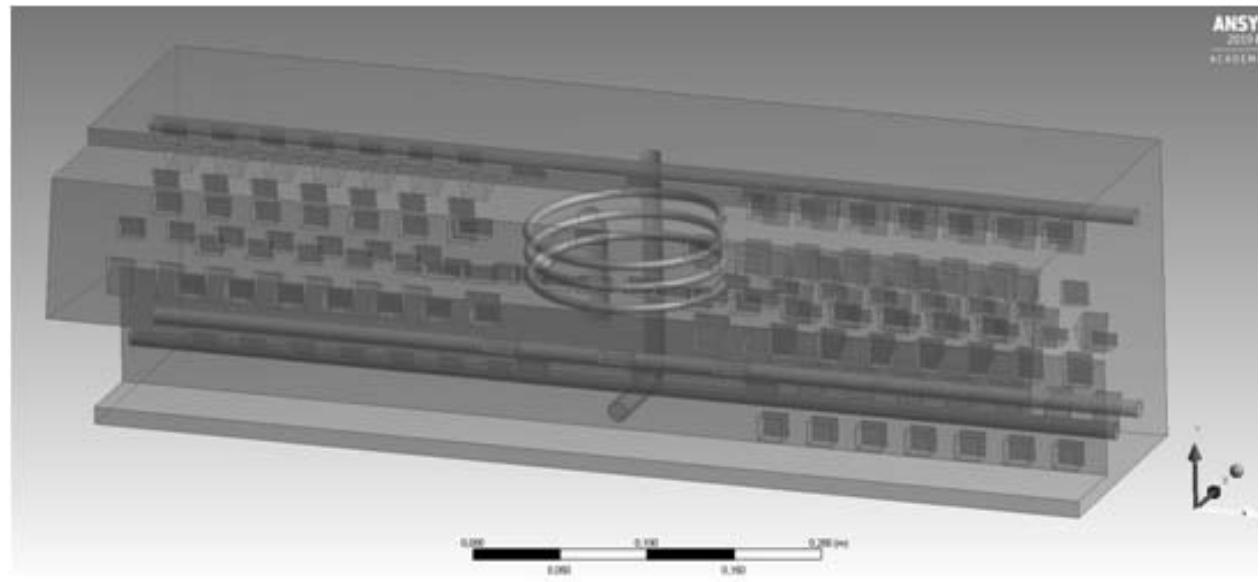

b

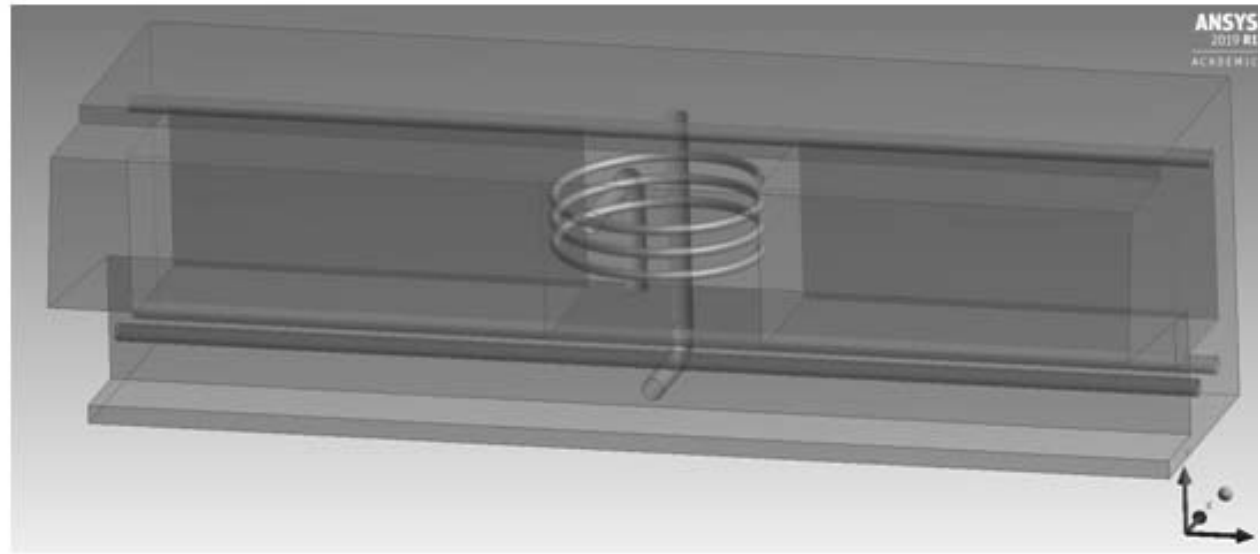

$\mathrm{c}$

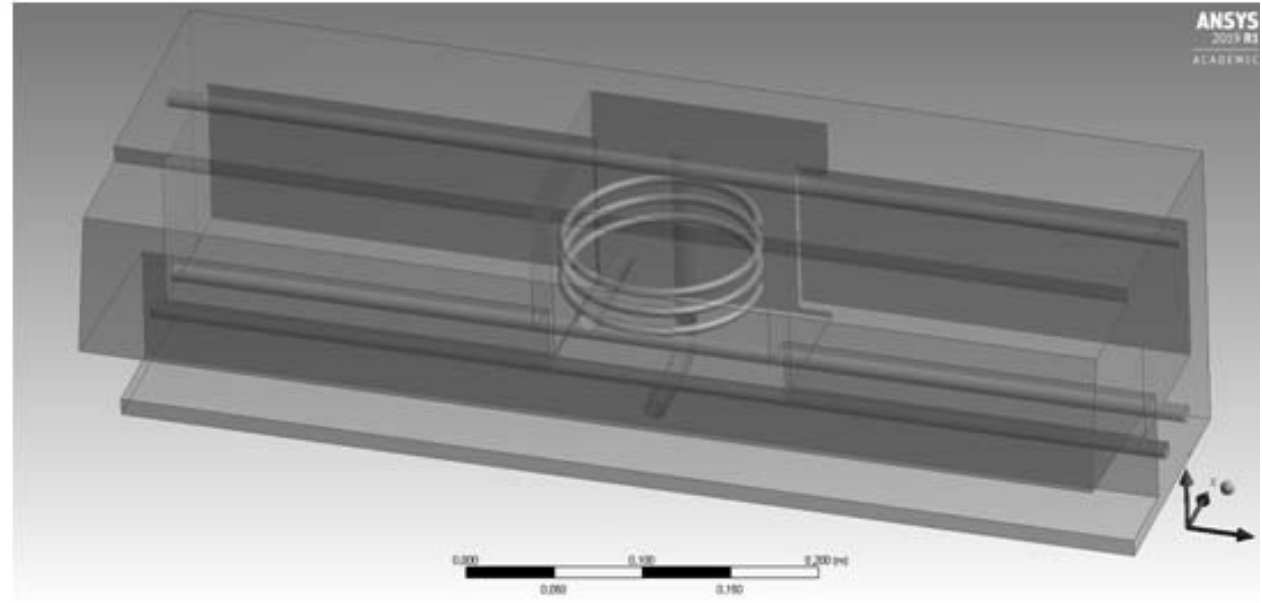

Rys. 5. Sposób odwzorowania raków w wypełnieniu złącza w modelach numerycznych serii obliczeniowej III: a - raki rozproszone równomiernie $\mathrm{w}$ wypełnieniu; $\mathrm{b}$ - raki zlokalizowane $\mathrm{w}$ wypełnieniu poza elementami zbrojenia złącza; c - raki zlokalizowane w wypełnieniu w obszarze zbrojenia złącza PS

Fig. 5. The imaging of the defects in completing the numerical models connectors Series III: a - efects evenly distributed in the filling; $\mathrm{b}$ - efects located in the filling outside of the joint reinforcement elements; $\mathrm{c}$ - efects located in the filling in the reinforcement area of the PS connector 
Górski, W., Szulc, J. (2019). Modelowanie numeryczne niejednorodności struktury wypełnienia złączy w budynkach wielkopłytowych. Acta Sci. Pol. Architectura 18 (2), 79-92, DOI: 10.22630/ASPA.2019.18.2.25

a

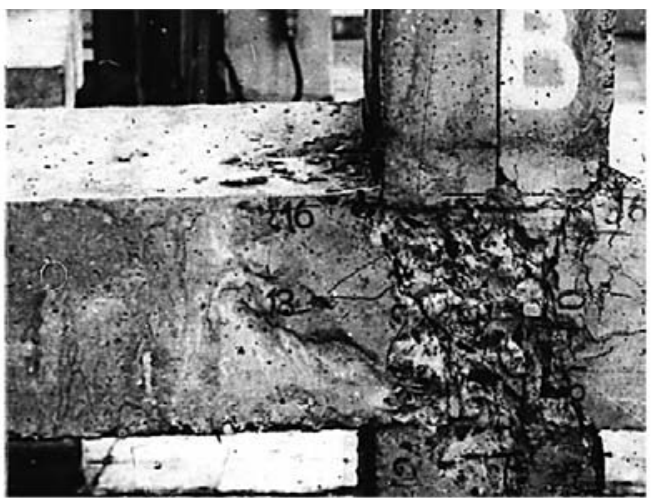

b

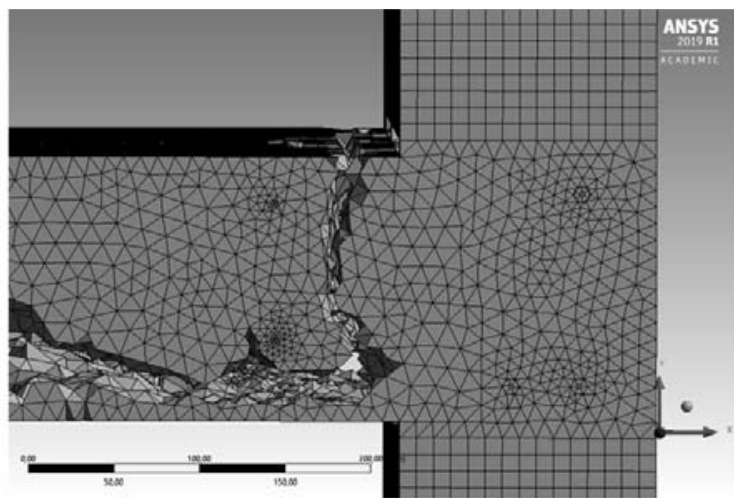

Rys. 6. Charakter zniszczenia złącza konstrukcyjnego Wk-70: a - model doświadczalny (Pogorzelski, 1982); b - model numeryczny

Fig. 6. The nature of the destruction of the Wk-70 structural joint: a - experimental model (Pogorzelski, 1982); b - numerical model

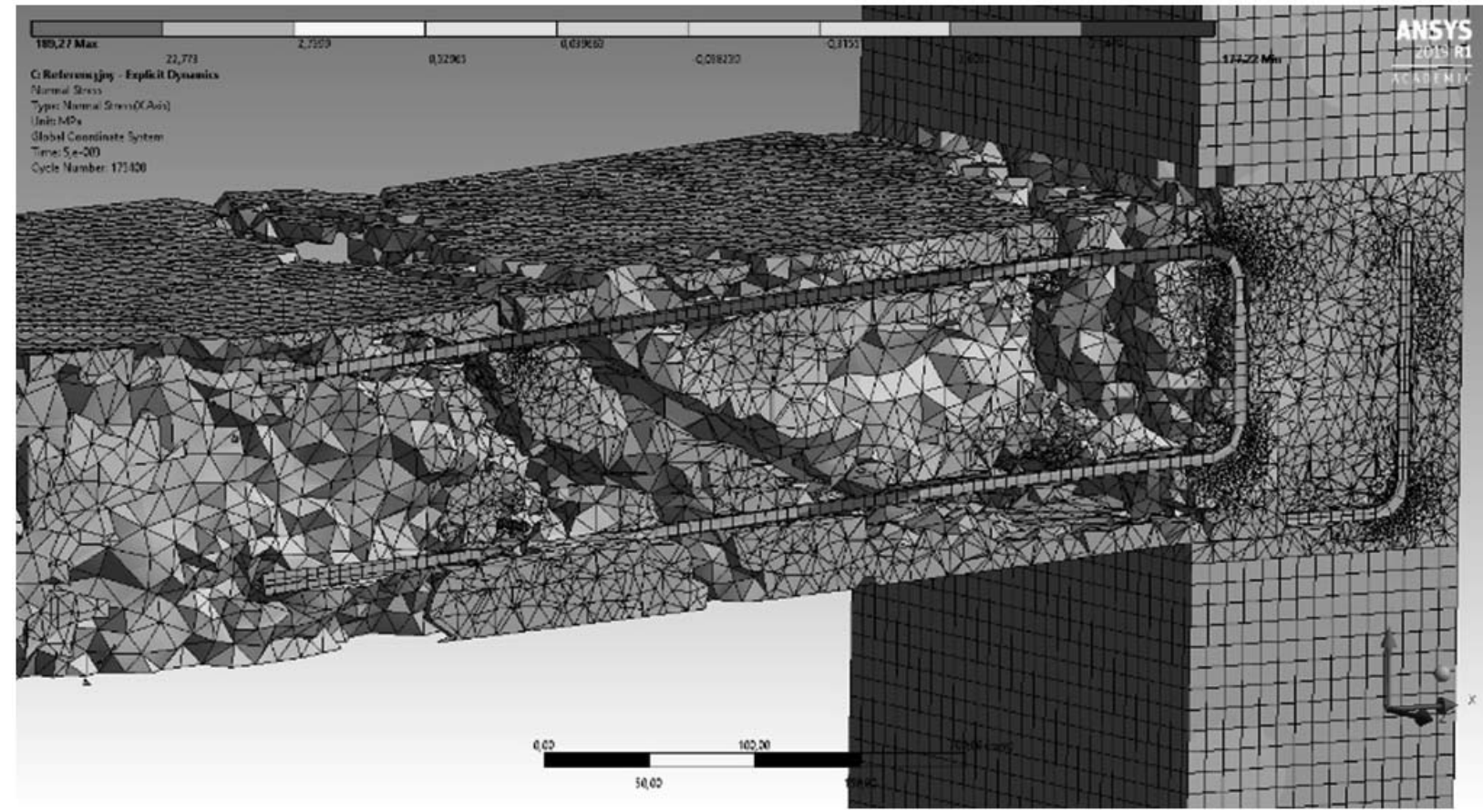

Rys. 7. Naprężenia normalne w elementach złącza (w przekroju pionowym przez pręt PG) - model I-1

Fig. 7. Normal stresses in joint elements (in vertical section through a PG rod) - Model I-1

Rozkłady naprężeń normalnych w wybranych elementach złącza przedstawiono na rysunkach 9 i 10; maksymalne wartości w PG złącza wyniosły $189 \mathrm{MPa}$. W pręcie PS wystąpiły ogniska naprężeń ściskających i rozciągających (rys. 10a) w miejscach kontaktu z prętami PL i PG.
W tym obszarze następował również znaczący wzrost naprężeń w materiale wypełniającym złącze i w konsekwencji została zainicjowana postępująca propagacja zarysowań/pęknięć prowadząca do zniszczenia złącza. 
Górski, W., Szulc J. (2019). Modelowanie numeryczne niejednorodności struktury wypełnienia złączy w budynkach wielkopłytowych. Acta Sci. Pol. Architectura 18 (2), 79-92, DOI: 10.22630/ASPA.2019.18.2.25
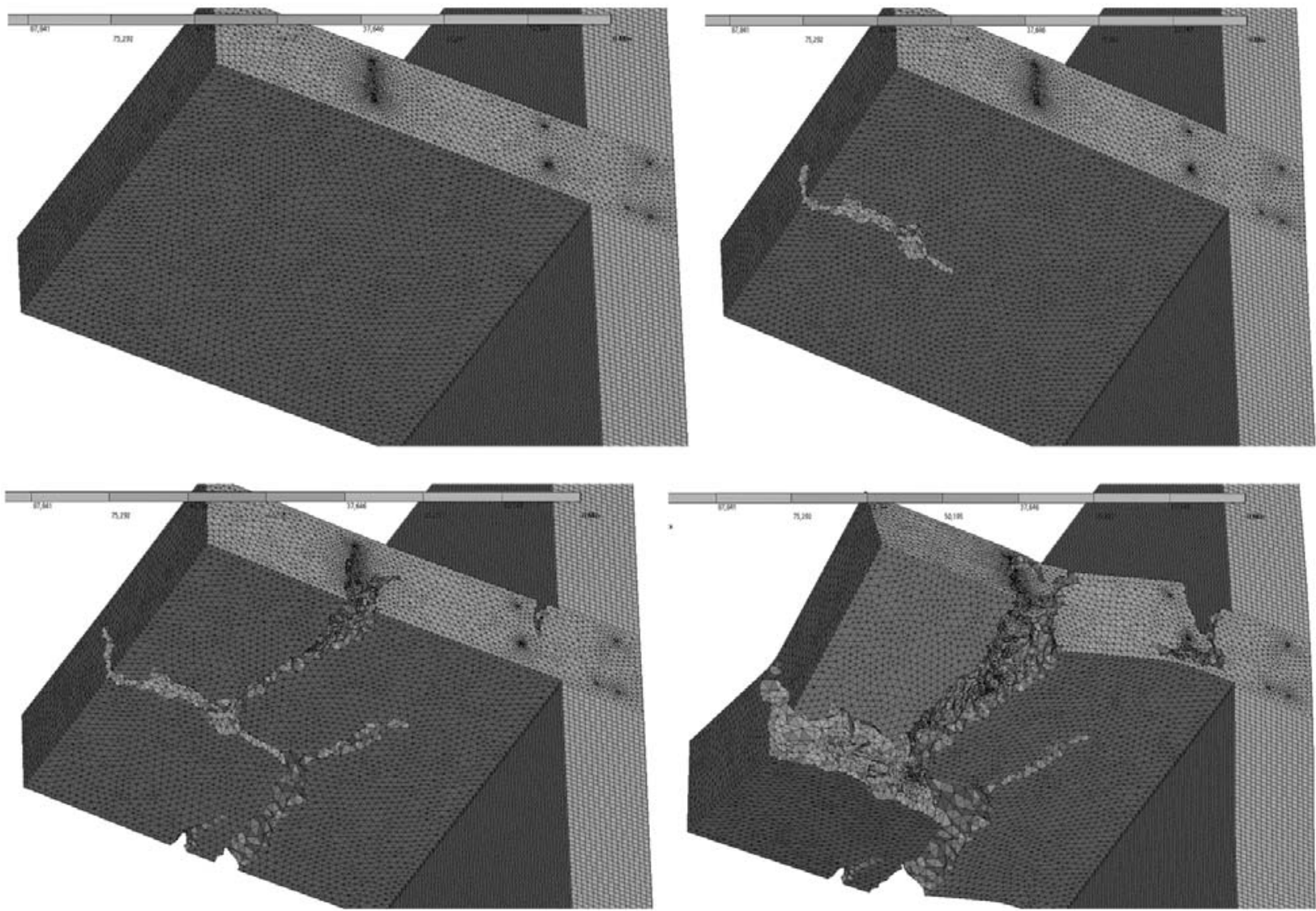

Rys. 8. Propagacja zarysowań i zniszczenie elementów złącza konstrukcyjnego

Fig. 8. Propagation of scratches and destruction of structural joint elements

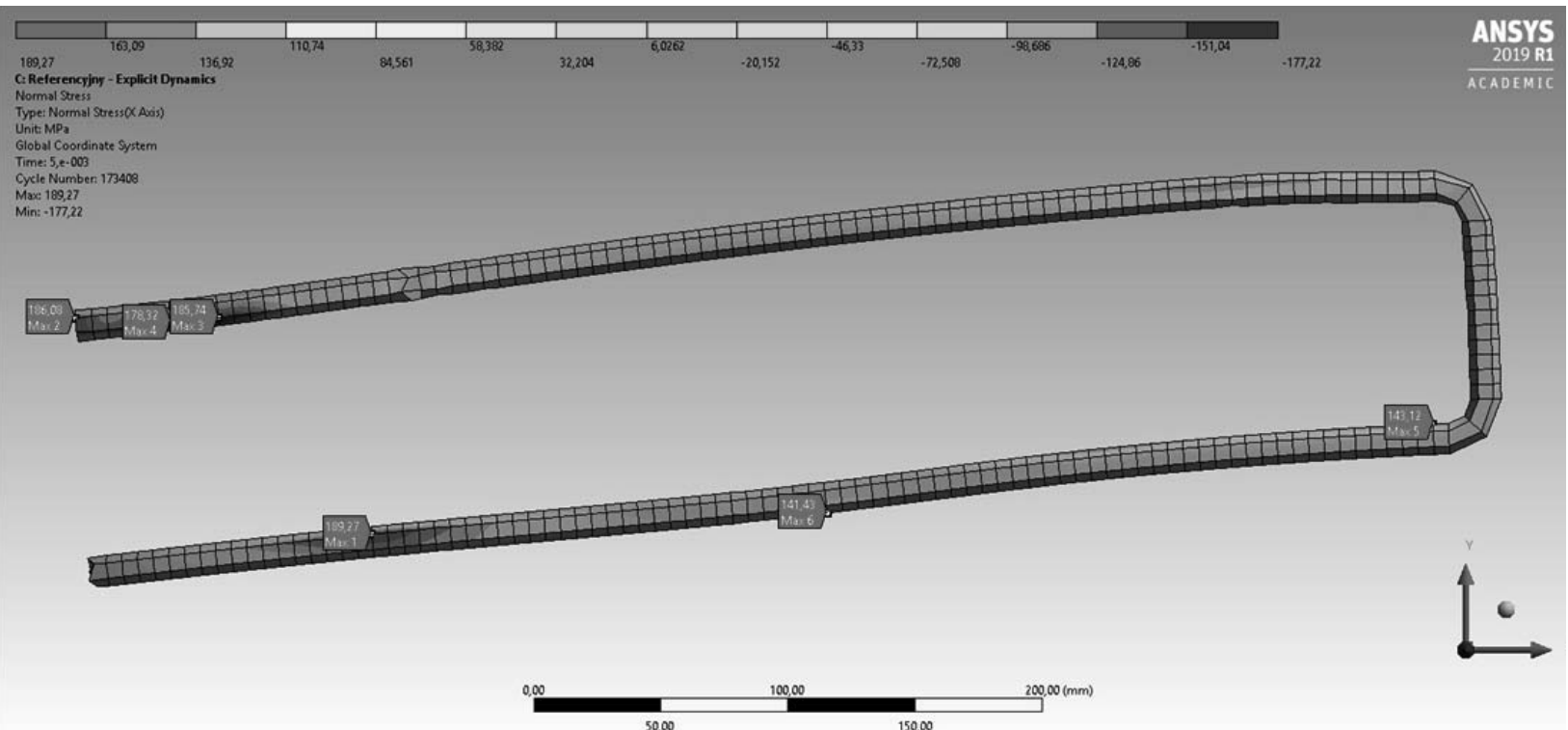

Rys. 9. Rozkłady naprężeń normalnych w elementach złącza: pręt PG, pręt PS, wypełnienie

Fig. 9. Distributions of normal stresses in joint elements: PG rod, PS rod, joint filling 


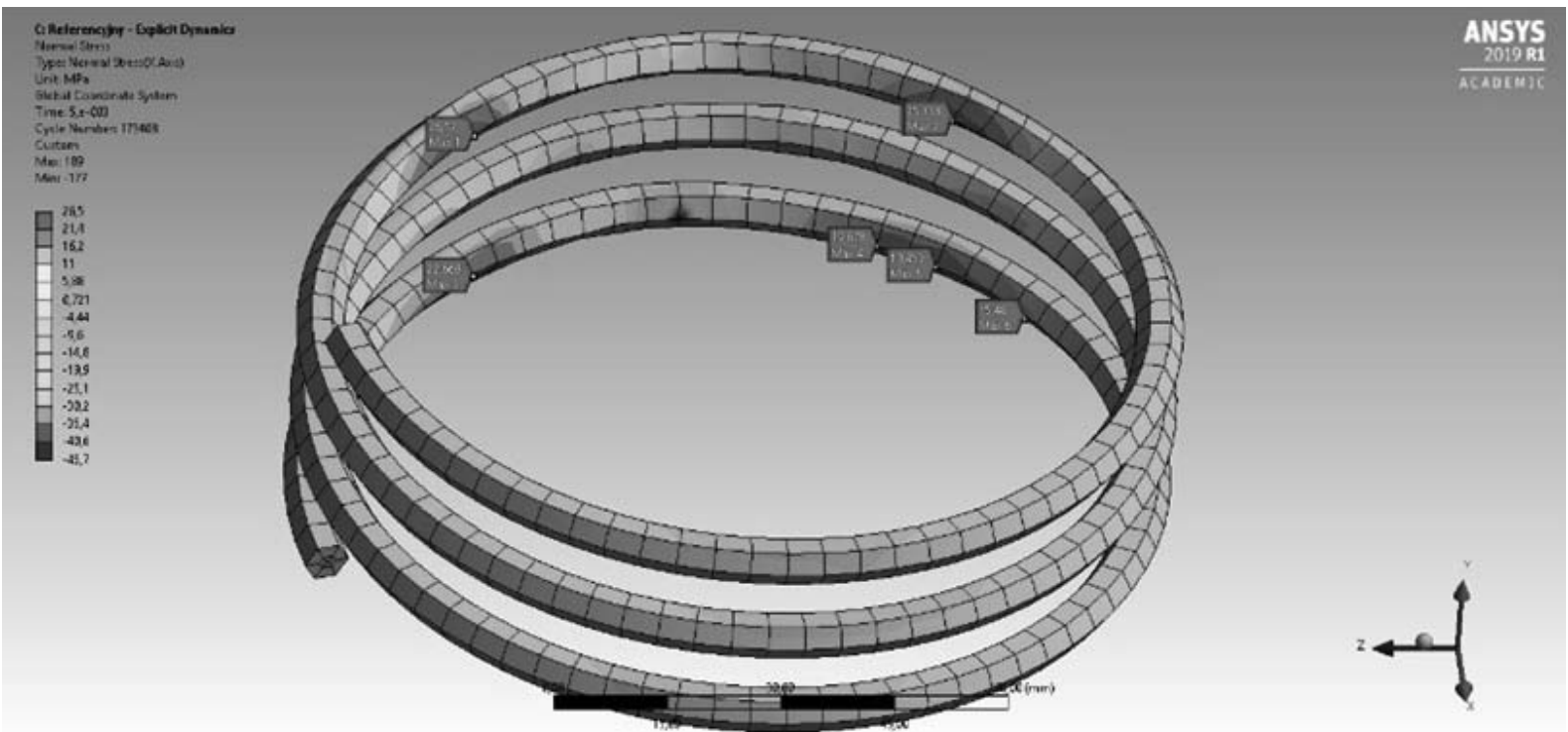

b

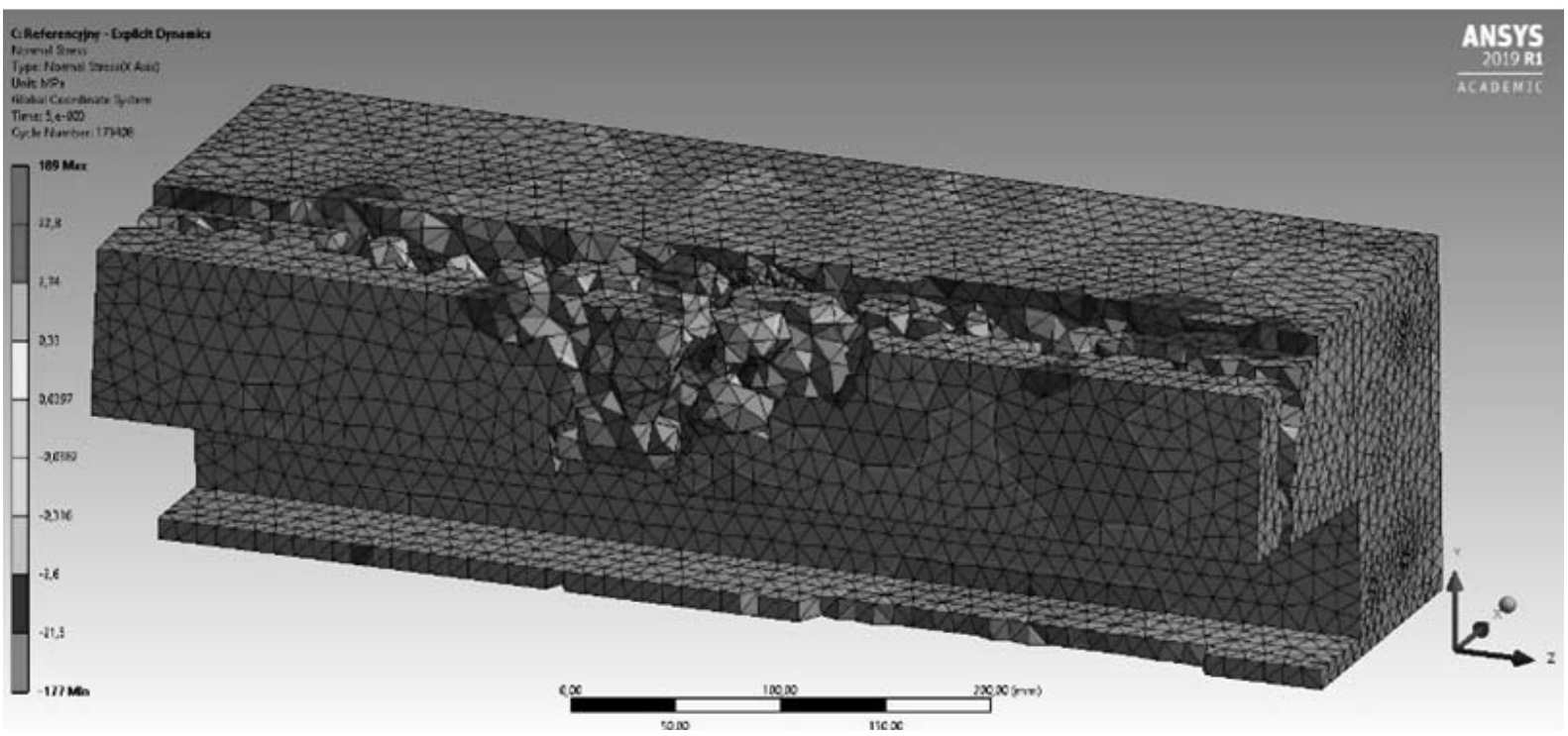

Rys. 10. Rozkłady naprężeń normalnych w elementach złącza: a - pręt PS; b - wypełnienie

Fig. 10. Distributions of normal stresses in joint elements: $a-P S$ rod; $b$ - joint filling

\section{Seria obliczeniowa II}

W modelu obliczeniowym II-1 maksymalne wartości naprężeń normalnych (w betonie wypełnienia złącza) wyniosły 16,4 MPa i zlokalizowane były w pobliżu podstawy bryły; w modelu II-2 (rys. 11a) nastąpił wzrost naprężeń ściskających do wartości 20,28 MPa (z jednoczesnym pojawieniem się naprężeń rozciągających na poziomie $0,42 \mathrm{MPa}$ ). Największy wzrost na- prężeń w betonie zanotowano w modelu II-3 (rys. 11b) zawierającym ostre krawędzie wewnętrznej nieciągłości struktury materiału wypełniającego złącze, w tym przypadku naprężenia ściskające osiągnęły wartość 36,6 MPa (naprężenia rozciągające do 4,1 MPa). $\mathrm{Z}$ uwagi na powyższe do analiz serii obliczeniowej III przyjęto raki odwzorowane jako prostopadłościany - co odpowiada stanowi rzeczywistemu (rys. 12). 
Górski, W., Szulc J. (2019). Modelowanie numeryczne niejednorodności struktury wypełnienia złączy w budynkach wielkopłytowych. Acta Sci. Pol. Architectura 18 (2), 79-92, DOI: 10.22630/ASPA.2019.18.2.25
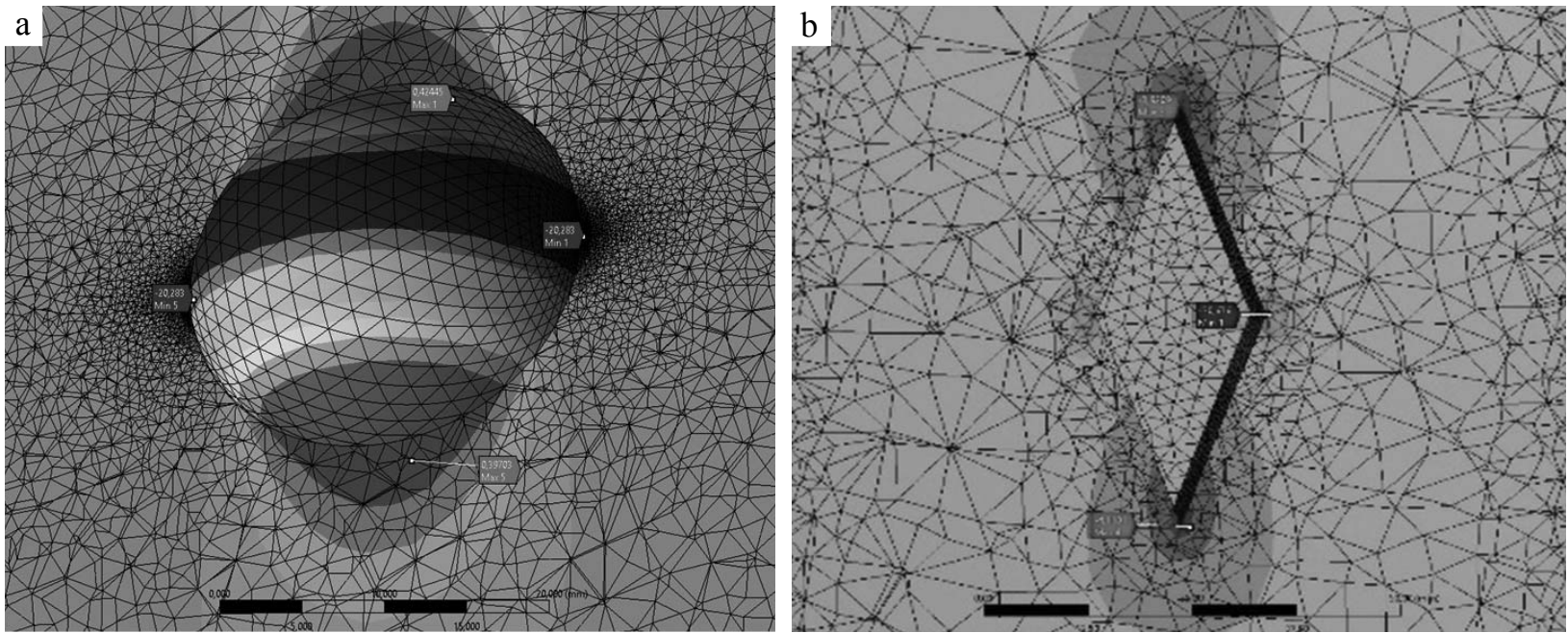

Rys. 11. Ekstremalne naprężenia normalne i ich koncentracje w obszarze raków: $a$ - model II-2; $b$ - model II-3

Fig. 11. Extreme normal stresses and their concentrations in the area of defects: $a-$ Model II-2; $b-$ Model II-3

a

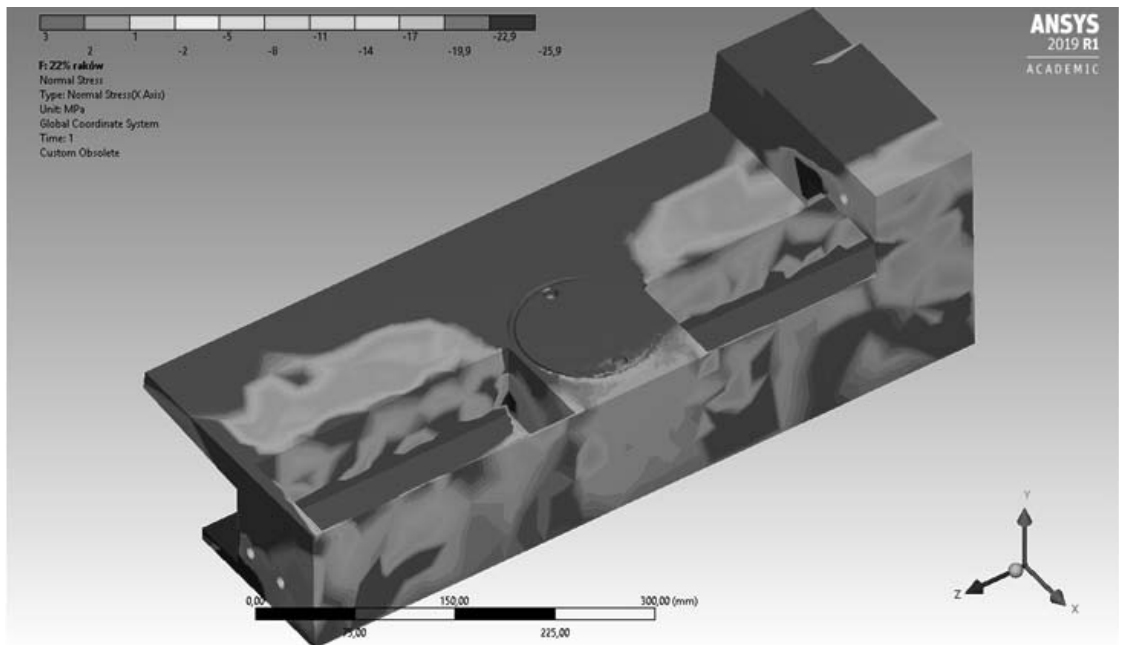

$\mathrm{b}$

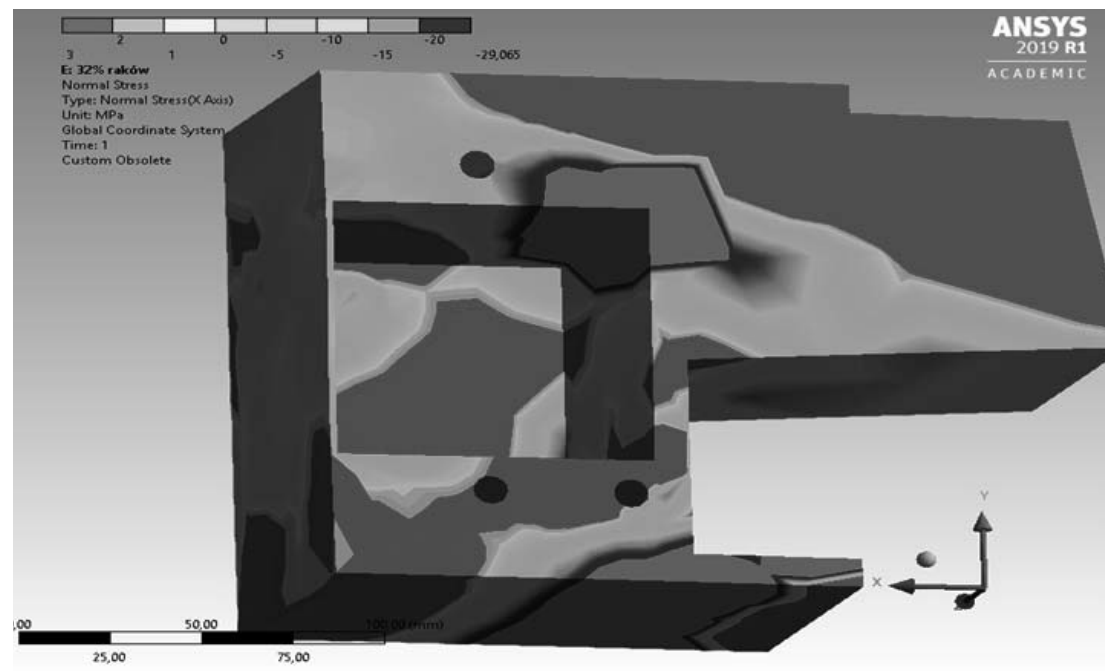

Rys. 12. Przykładowe mapy rozkładu naprężeń normalnych w wypełnieniu złącza z rakami: $a$ - model III-3; b - model III-4

Fig. 12. Exemplary maps of normal stresses in filling the joint with defects: $a$ - Model III-3; $b$ - Model III-4 
Górski, W., Szulc, J. (2019). Modelowanie numeryczne niejednorodności struktury wypełnienia złączy w budynkach wielkopłytowych. Acta Sci. Pol. Architectura 18 (2), 79-92, DOI: 10.22630/ASPA.2019.18.2.25

\section{Seria obliczeniowa III}

Nieciągłości struktury betonu w elemencie konstrukcyjnym (w postaci raków) są zwykle niepożądane; dopuszcza się jednak ich lokalne występowanie pod warunkiem, że nie obejmują więcej niż 3\% przekroju elementu - w odniesieniu do powierzchni minimum 0,1 $\mathrm{m}^{2}$ (Runkiewicz, Szudrowicz, Geryło, Szulc i Sieczkowski, 2014a; 2014b).

$\mathrm{W}$ elemencie wypełnienia złącza w modelu III-2 nastąpił wzrost (w odniesieniu do modelu wyjściowe- go III-1) naprężeń ściskających w dolnej części pręta PG z 89,65 do 121,58 MPa i niewielki spadek naprężeń rozciągających od 190,46 do 182,67 MPa. Taki trend związany był z przekroczeniem naprężeń rozciągających w wypełnieniu złącza i przejęciem części obciążenia przez dolny odcinek pręta PG. Pojawienie się pęknięć spowodowało również wzrost przemieszczeń o $35 \%$ (z 2,24 do 3,03 mm).

Przekrój przez wypełnienie złącza modelu II-2 wskazuje koncentrację naprężeń na krawędziach de-

a

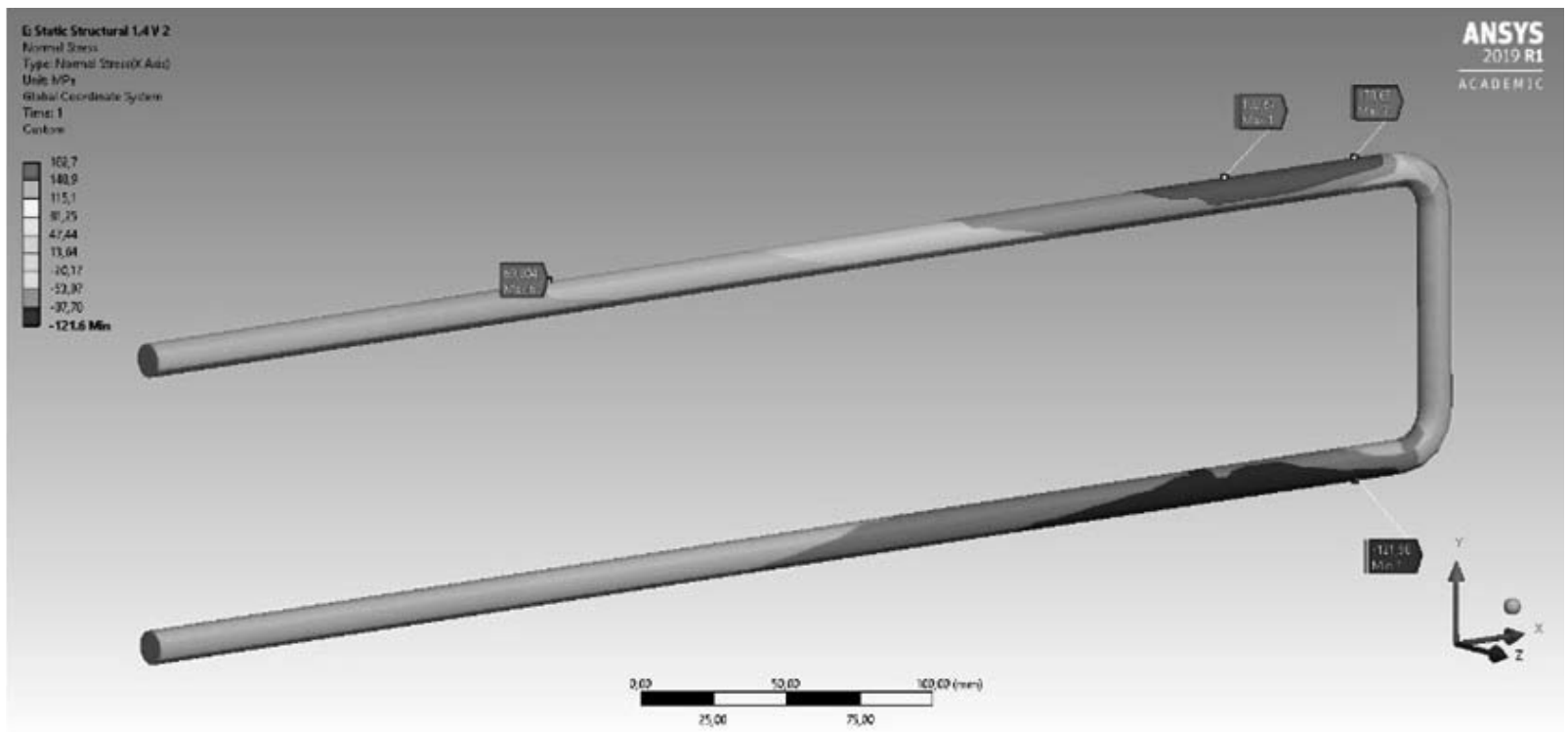

b

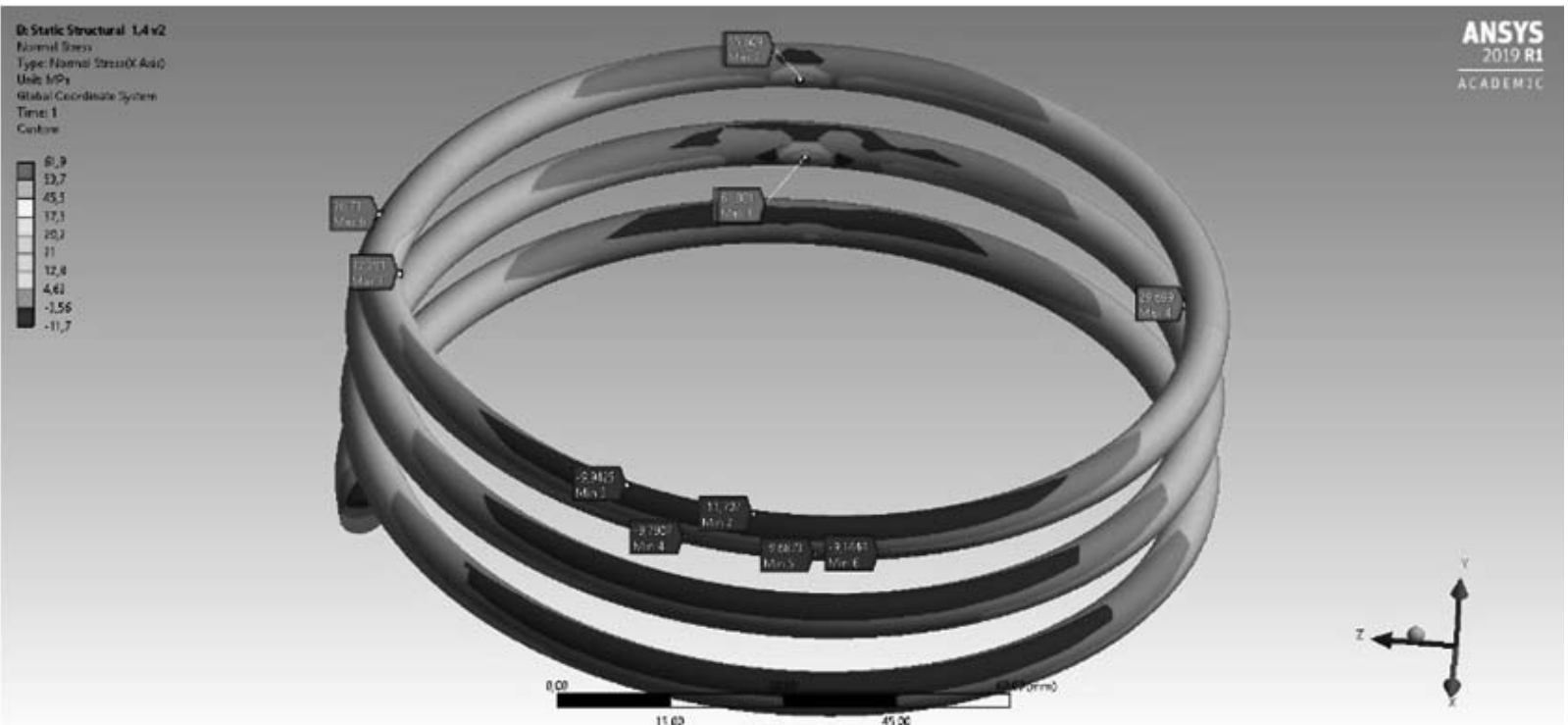

Rys. 13. Wyniki analiz numerycznych modeli złączy z rakami w wypełnieniu - naprężenia normalne w prętach PG i PS: $a$ - model III- $2 ; b$ - model III-3

Fig. 13. The results of numerical analyses of models of joints with defects in filling - normal stresses in PG and PS rods: a - Model III-2; b - Model III-3 
Górski, W., Szulc J. (2019). Modelowanie numeryczne niejednorodności struktury wypełnienia złączy w budynkach wielkopłytowych. Acta Sci. Pol. Architectura 18 (2), 79-92, DOI: 10.22630/ASPA.2019.18.2.25

fektów; jest to również wyraźnie widoczne w modelach III-3 i III-4 (rys. 13 i 14). Dużo wyższy poziom udziału objętościowego defektów (nasycenia) dla tych modeli obliczeniowych stanowi przyczynę uszkodzenie znacznej części wypełnienia złącza konstrukcyjnego oraz ścian i płyty stropowej w wyniku znacznego wzrostu odkształceń w betonie. Zmniejszenie udziału betonu w przenoszeniu naprężeń prowadzi jednocześnie do wzrostu wytężenia zbrojenia. W modelu III-4 naprężenia rozciągające i ściskające osiągają wartości odpowiednio 319,25 i 312,89 MPa, a w modelu III-3 odpowiednio 240,25 i 292,56 MPa (rys. 14).

\section{PODSUMOWANIE}

Przeprowadzone analizy numeryczne z wykorzystaniem MES ( $w$ środowisku programu ANSYS) pozwoliły określić potencjalny wpływ nieciągłości materiałowych na pracę złączy konstrukcyjnych stosowanych

a

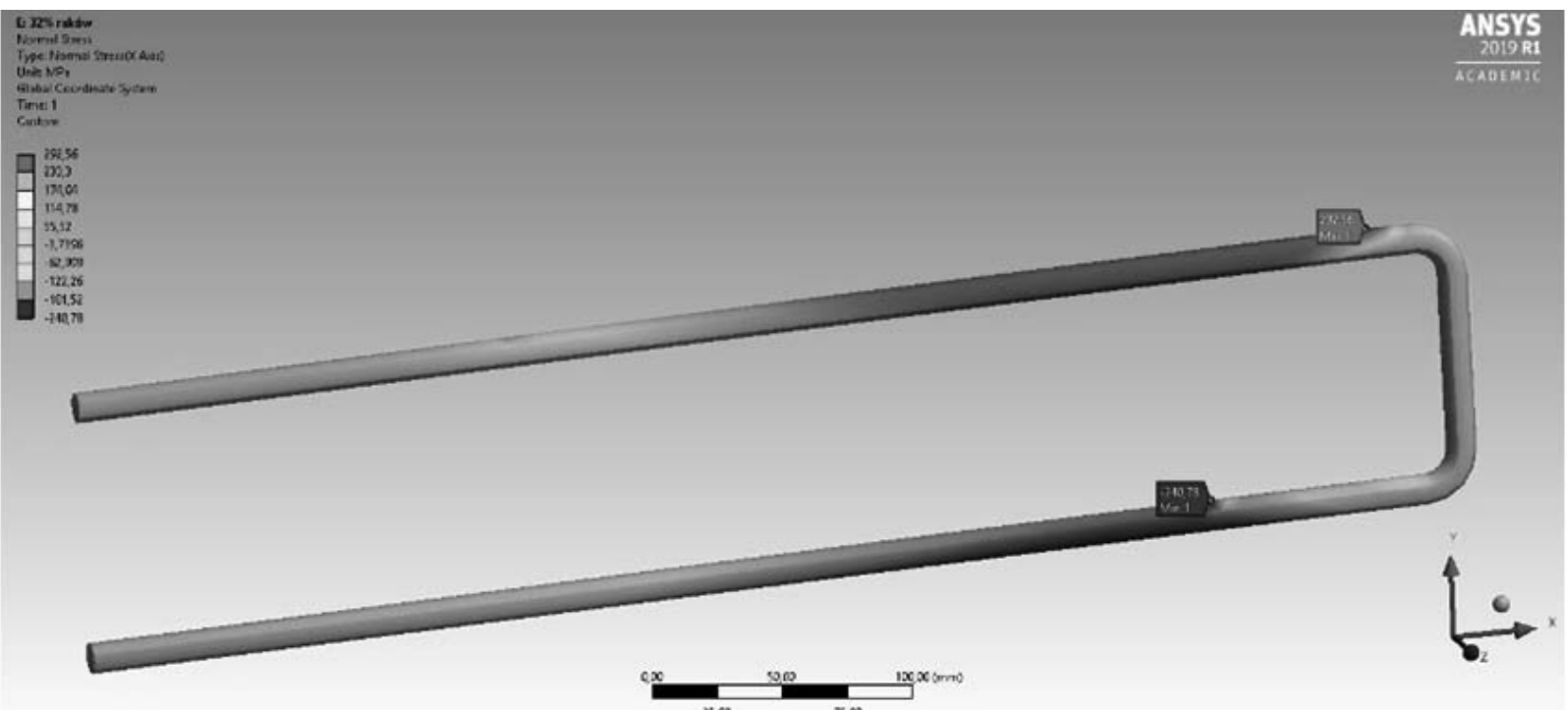

b

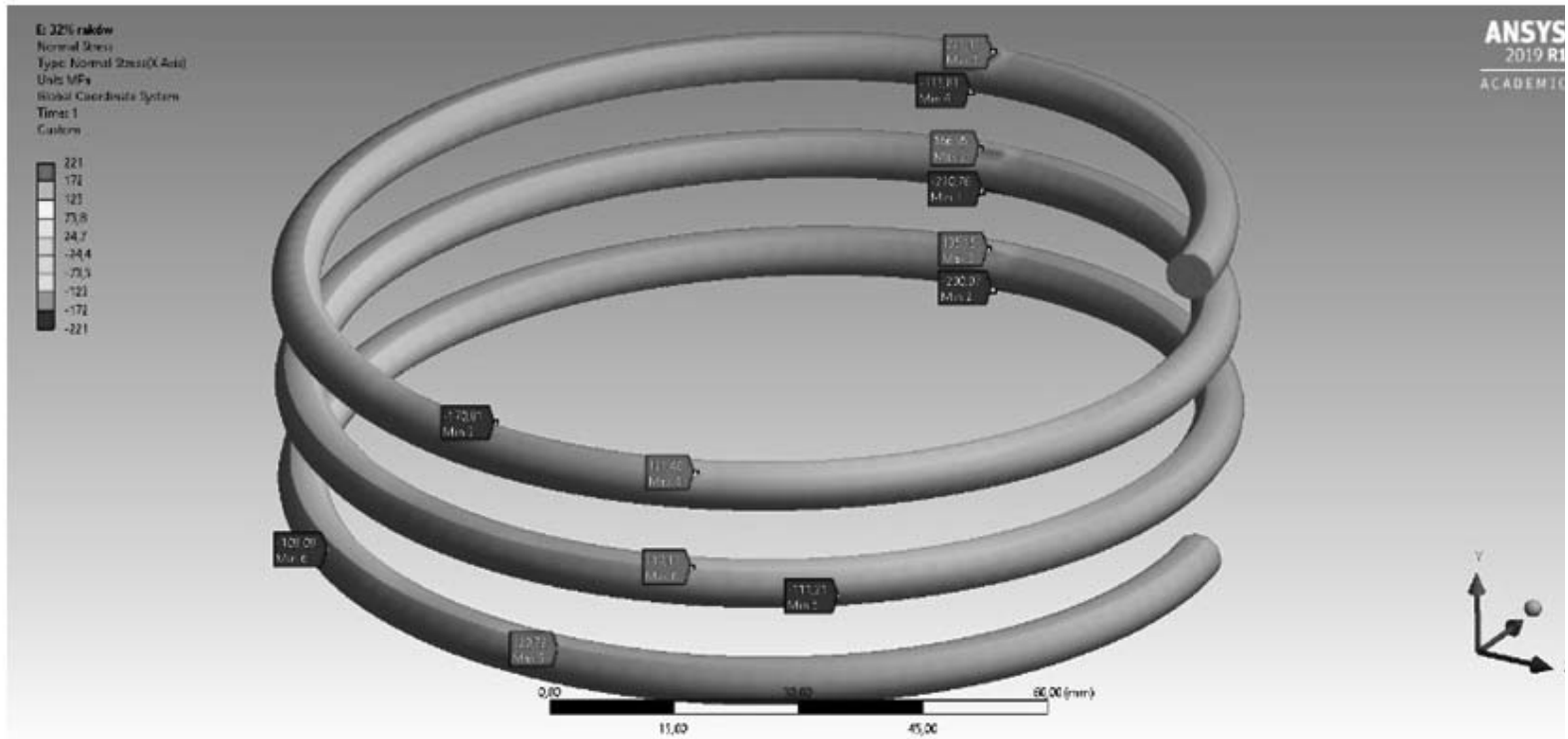

Rys. 14. Wyniki analiz numerycznych dla modelu III-4, złącze z rakami w wypełnieniu - naprężenia normalne w prętach PG i PS (model III-4)

Fig. 14. The results of numerical analyses of models of joints with defects in filling - normal stresses in PG and PS rods (Model III-4) 
do połączeń elementów w ustrojach nośnych budynków wielkopłytowych.

Przeprowadzone serie obliczeniowe wykazały jakościową i ilościową zależność stanu naprężenia oraz odkształcenia materiałów wypełnienia złączy od występujących w nich defektów w zakresie kształtu (tzw. raków), ich lokalizacji i nasycenia w strukturze objętościowej wypełnienia. Uzyskane wyniki pozwalają oszacować rzeczywisty spadek sztywności złączy i jego wpływ na prace przestrzenną ustroju konstrukcyjnego budynków wielkopłytowych, umożliwiają więc określenie poziomu ewentualnego zagrożenia bezpieczeństwa użytkowania i podjęcie właściwych czynności zaradczych.

Modelowanie numeryczne złączy może stanowić wspomagające badania in situ, narzędzie oceny stanu technicznego budynków wielkopłytowych oraz podstawę podejmowania decyzji o ewentualnym wzmocnieniu konstrukcji przy określonym obliczeniowo poziomie zagrożenia bezpieczeństwa użytkowania budynku.

\section{Adnotacja}

W artykule zaprezentowano wyniki badań otrzymane z użyciem oprogramowania pakietu ANSYS dostarczonego przez firmę MESco.

\section{PIŚMIENNICTWO}

Dębowski, J. (2012a). Cała prawda o budynkach wielkopłytowych. Przeglad Budowlany, 83 (9), 28-35.

Dębowski, J. (2012b). Typowe uszkodzenia w budynkach wielkopłytowych. Przeglad Budowlany, 83 (10), 25-32.
Ligęza, W. (2014). Budownictwo wielkopłytowe po latach. Wybrane problemy remontowe. Budownictwo i Architektura, 13 (3), 15-25.

Ligęza, W. (2015). Synteza zagadnień technicznych w rewitalizacji budynków wielkopłytowych. Przeglad Budowlany, 86 (6), 60-66

Ligęza, W. i Dębowski, J. (2007). Identyfikacja uszkodzeń elementów wielkopłytowych w aspekcie oceny bezpieczeństwa eksploatacyjnego budynku. Zapobieganie, diagnostyka, naprawy, rekonstrukcje. W XXIII Konferencja Naukowo-Techniczna „Awarie budowla$n e "$ Szczecin-Międzyzdroje (strony 741-748). Szczecin: Politechnika Szczecińska.

Pogorzelski, A. (1982). Praca złacza poziomego strop ściana w budynkach wielkoptytowych (rozprawa doktorska). Warszawa: ITB.

Runkiewicz, L., Szudrowicz, B., Geryło, R., Szulc, J. i Sieczkowski, J. (2014a). Diagnostyka i modernizacja budynków wielkopłytowych (cz. 1). Przeglad Budowlany, 85 (7-8), 54-60.

Runkiewicz, L., Szudrowicz, B., Geryło, R., Szulc, J. i Sieczkowski, J. (2014b). Diagnostyka i modernizacja budynków wielkopłytowych (cz. 2). Przeglad Budowlany, 85 (9), 20-26.

Szulc, J. (2017). Procedury diagnostyczne budynków wielkopłytowych. Materiały Budowlane, 8, 29-31.

Szulc, J. (2018). Techniczne możliwości modernizacji budynków z wielkiej płyty. Izolacje, 23 (2), 14-23.

Szulc, J. (2019a). Ogólny stan techniczny budynków wielkopłytowych w aspekcie historycznych nieprawidłowości systemowych. Izolacje, 24 (3), 46-54.

Szulc, J. (2019b). Możliwości techniczne napraw lub wzmocnienia budynków z wielkiej płyty. Izolacje, 24 (2), 26-32.

\section{NUMERICAL MODELLING OF NON-HOMOGENEOUS CONCRETE CONNECTION IN LARGE PANEL SYSTEM BUILDINGS}

\section{ABSTRACT}

The paper deals with the issue of safety and durability of the buildings built in large panel building system in the 1960-1990. During this period, at the various stages of the investment process, there were many irregularities, which could have resulted in a reduction in the quality of the performance of buildings and caused of a number of different defects among others in the area of structural joints between precast. The article indicates the possibility of using numerical modelling to evaluate the work of joints, in which, for 
example, there is a heterogeneity of the structure of the filling material (so-called cancers). Horizontal joints of the ceiling and internal supporting wall made in the central system Wk-70; were chosen for the analyses. The paper presents the results of variant computer simulations of the so-called work reference joints and joints containing variable share, distribution and shape of defects. The results of calculations can constitute the basis for determining the directions of diagnostic works of large panel buildings, assessment the technical condition of the structure and eventual the decision to repair or strengthen them.

Key words: large panel buildings, Wk-70, concrete connection, finite element method, defects, technical assessment 